SGW-39299

Revision 0

\title{
Results of Groundwater
} Monitoring for the 183-H Solar Evaporation Basins and 300 Area Process

\section{Trenches}

\section{January - June 2008}

Prepared for the U.S. Department of Energy

Assistant Secretary for Environmental Management

Project Hanford Management Contractor for the

U.S. Department of Energy under Contract DE-AC06-96RL13200

\section{FLUOR}

P.O. Box 1000

Richland, Washington 
SGW-39299

Revision 0

\section{Results of Groundwater Monitoring for the 183-H Solar Evaporation Basins and 300 Area Process Trenches}

January - June 2008

Document Type: TR

Program/Project: SGW

M. J. Hartman

Fluor Hanford, Inc.

Date Published

October 2008

Prepared for the U.S. Department of Energy

Assistant Secretary for Environmental Management

Project Hanford Management Contractor for the

U.S. Department of Energy under Contract DE-AC06-96RL13200

\section{FLUOR。}

P.O. Box 1000

Richland, Washington

$\frac{\text { A. D. Aandal }}{\text { Gélease Approval }} \frac{11 / 04 / 2008}{\text { Date }}$ 
TRADEMARK DISCLAIMER

Reference herein to any specific commercial product, process,

or service by trade name, trademark, manufacturer, or

otherwise, does not necessarily constitute or imply its

endorsement, recommendation, or favoring by the United

States Government or any agency thereof or its contractors or subcontractors.

This report has been reproduced from the best available copy. 
SGW-39299, Rev. 0

\section{EXECUTIVE SUMMARY}

This is one of a series of reports on Resource Conservation and Recovery Act of 1976 (RCRA) monitoring at the 183-H solar evaporation basins and the 300 Area process trenches. It fulfills the requirement of Washington Administrative Code (WAC) 173-303-645(11)(g), "Release from Regulated Units," to report twice each year on the effectiveness of the corrective action program. This report covers the period from January through June 2008.

The current objective of corrective action monitoring the $183-\mathrm{H}$ basins is simply to track trends. Although there is short-term variability in contaminant concentrations, trends over the past 10 years are downward. The current Hanford Facility RCRA Permit (Dangerous Waste Portion of the Resource Conservation and Recovery Act Permit for the Treatment, Storage, and Disposal of Dangerous Waste [Permit No. WA 7890008967]) and monitoring plan remain adequate for the objective of tracking trends.

The objective of groundwater monitoring at the 300 Area process trenches is to demonstrate the effectiveness of the corrective action program by examining the trend of the constituents of interest to confirm that they are attenuating naturally. The overall concentration of uranium in network wells remained above the $30 \mu \mathrm{g} / \mathrm{L}$ drinking water standard in the three downgradient wells screened at the water table. Fluctuations of uranium concentration are caused by changes in river stage. The concentration of cis-1,2-dichloroethene remained above the $70 \mu \mathrm{g} / \mathrm{L}$ drinking water standard in one well (399-1-16B). Concentrations are relatively steady at this well and are not affected by river stage. Trichloroethene and tetrachloroethene concentrations were below detection limits in all wells during the reporting period. 
SGW-39299, Rev. 0

This page intentionally left blank.

ES-2 


\section{TABLE OF CONTENTS}

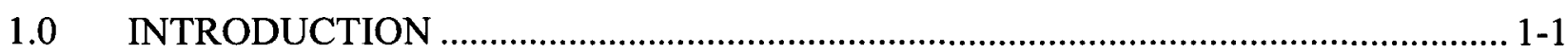

2.0 183-H SOLAR EVAPORATION BASINS........................................................ 2-1

$2.1 \quad$ 100-HR-3 INTERIM REMEDIAL ACTION ................................................... 2-2

2.2 RCRA GROUNDWATER MONITORING PROGRAM FOR 183-H BASINS ............................................................................................ 2-2

2.3 CONTAMINANT TRENDS FOR 183-H BASINS ........................................ 2-3

$2.4 \quad 183-\mathrm{H}$ BASINS CONCLUSIONS ............................................................ 2-8

$3.0 \quad 300$ AREA PROCESS TRENCHES................................................................

3.1 RCRA GROUNDWATER MONITORING PROGRAM FOR 300 AREA PROCESS TRENCHES.............................................................................. 3-1

3.2 CONTAMINANT TRENDS FOR 300 AREA PROCESS TRENCHES............ 3-2

3.2.1 Uranium ........................................................................... 3-2

3.2.2 Cis-1,2-Dichloroethene ................................................................... 3-5

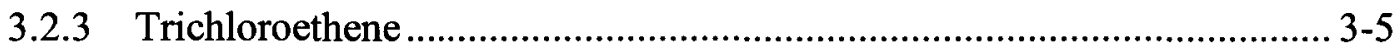

3.2.4 Tetrachloroethene ...................................................................... 3-8

$3.3 \quad 300$ AREA PROCESS TRENCHES CONCLUSIONS................................... 3-8

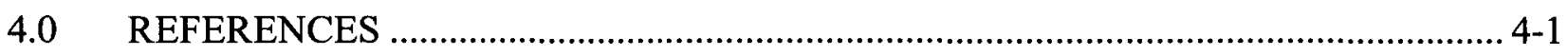

\section{FIGURES}

Figure 2-1. Monitoring Well Locations for 183-H (116-H-6) Basins. ................................... 2-3

Figure 2-2. Hexavalent Chromium Concentrations in 183-H Wells. ...................................... 2-5

Figure 2-3. Nitrate Concentrations in 183-H Monitoring Wells Sampled During the

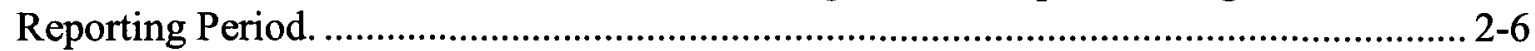

Figure 2-4. Technetium-99 Concentrations in 183-H Monitoring Wells Sampled

During the Reporting Period................................................................................... 2-7

Figure 2-5. Uranium Concentrations in 183-H Monitoring Wells Sampled During the Reporting Period. ........................................................................................... 2-8

Figure 3-1. Locations of Wells in the 300 Area Process Trenches Monitoring

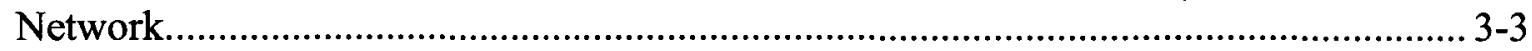

Figure 3-2. Uranium Concentrations in Well 399-1-10A................................................. 3-6

Figure 3-3. Uranium Concentrations in Well 399-1-16A.................................................... 3-6

Figure 3-4. Uranium Concentrations in Well 399-1-17A................................................... 3-7

Figure 3-5. Cis-1,2-Dichloroethene Concentrations in Well 399-1-16B................................ 3-7 
SGW-39299, Rev. 0

\section{TABLES}

Table 2-1. 183-H Basins Groundwater Plume Concentration Limits..................................... 2-1

Table 2-2. Groundwater Data for 183-H Basins, January Through June 2008....................... 2-4

Table 3-1. Concentration Limits for 300 Area Process Trenches............................................ 3-2

Table 3-2. Groundwater Data for 300 Area Process Trenches, January Through

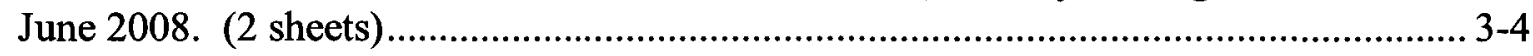


SGW-39299, Rev. 0

\section{LIST OF TERMS}

CERCLA Comprehensive Environmental Response, Compensation, and Liability Act of 1980

DWS

drinking water standard

OU

PCE

operable unit

RCRA

ROD

TCE

tetrachloroethene

Resource Conservation and Recovery Act of 1976

Record of Decision

WAC

trichloroethene

Washington Administrative Code 
SGW-39299, Rev. 0

This page intentionally left blank. 
SGW-39299, Rev. 0

\section{METRIC CONVERSION CHART}

\begin{tabular}{|c|c|c|c|c|c|}
\hline \multicolumn{3}{|c|}{ Into Metric Units } & \multicolumn{3}{|c|}{ Out of Metric Units } \\
\hline If You Know & Multiply By & To Get & If You Know & Multiply By & To Get \\
\hline Length & & & Length & & \\
\hline inches & 25.4 & millimeters & millimeters & 0.039 & inches \\
\hline inches & 2.54 & centimeters & centimeters & 0.394 & inches \\
\hline feet & 0.305 & meters & meters & 3.281 & feet \\
\hline yards & 0.914 & meters & meters & 1.094 & yards \\
\hline miles & 1.609 & kilometers & kilometers & 0.621 & miles \\
\hline Area & & & Area & & \\
\hline sq. inches & 6.452 & sq. centimeters & sq. centimeters & 0.155 & sq. inches \\
\hline sq. feet & 0.093 & sq. meters & sq. meters & 10.76 & sq. feet \\
\hline sq. yards & 0.836 & sq. meters & sq. meters & 1.196 & sq. yards \\
\hline sq. miles & 2.6 & sq. kilometers & sq. kilometers & 0.4 & sq. miles \\
\hline acres & 0.405 & hectares & hectares & 2.47 & acres \\
\hline Mass (weight) & & & Mass (weight) & & \\
\hline ounces & 28.35 & grams & grams & 0.035 & ounces \\
\hline pounds & 0.454 & kilograms & kilograms & 2.205 & pounds \\
\hline ton & 0.907 & metric ton & metric ton & 1.102 & ton \\
\hline Volume & & & Volume & & \\
\hline teaspoons & 5 & milliliters & milliliters & 0.033 & fluid ounces \\
\hline tablespoons & 15 & milliliters & liters & 2.1 & pints \\
\hline fluid ounces & 30 & milliliters & liters & 1.057 & quarts \\
\hline cups & 0.24 & liters & liters & 0.264 & gallons \\
\hline pints & 0.47 & liters & cubic meters & 35.315 & cubic feet \\
\hline quarts & 0.95 & liters & cubic meters & 1.308 & cubic yards \\
\hline gallons & 3.8 & liters & & & \\
\hline cubic feet & 0.028 & cubic meters & & & \\
\hline cubic yards & 0.765 & cubic meters & & & \\
\hline Temperature & & & Temperature & & \\
\hline Fahrenheit & $\begin{array}{l}\text { subtract } 32 \text {, } \\
\text { then } \\
\text { multiply by } \\
5 / 9\end{array}$ & Celsius & Celsius & $\begin{array}{l}\text { multiply by } \\
9 / 5 \text {, then add } \\
32\end{array}$ & Fahrenheit \\
\hline Radioactivity & & & Radioactivity & & \\
\hline picocuries & 37 & millibecquerels & millibecquerels & 0.027 & picocuries \\
\hline
\end{tabular}


SGW-39299, Rev. 0

This page intentionally left blank. 


\subsection{INTRODUCTION}

This is one of a series of reports on Resource Conservation and Recovery Act of 1976 (RCRA) groundwater monitoring. It fulfills the requirement of Washington Administrative Code (WAC) 173-303-645(11)(g), "Release from Regulated Units," to report twice each year on the effectiveness of the corrective action program. This report covers the period from January through June 2008.

Semi-annual reports for the 183-H solar evaporation basins (183-H basins; 116-H-6 waste site) and the 300 Area process trenches (316-5 waste site) were formerly published separately (e.g., Results of Groundwater Monitoring for the 300 Area Process Trenches, Reporting Period July-December 2007 [SGW-27292], and Results of Groundwater Monitoring for the 183-H Solar Evaporation Basins, Reporting Period July-December 2007 [SGW-37294]). The two sites have been combined in this report. Section 2.0 presents information for the $183-\mathrm{H}$ basins, and Section 3.0 presents information for the 300 Area process trenches. 
SGW-39299, Rev. 0

This page intentionally left blank. 


\section{$2.0 \quad$ 183-H SOLAR EVAPORATION BASINS}

The 183-H basins were located in the 100-H Area of the Hanford Site and have been demolished and backfilled under the RCRA in the Hanford Facility RCRA Permit (Dangerous Waste Portion of the Resource Conservation and Recovery Act Permit for the Treatment, Storage, and Disposal of Dangerous Waste [Permit No. WA 7890008967]). Post-closure actions remain for the 183-H basins. Groundwater is monitored in accordance with WAC 173-303-645(11), "Corrective Action Program," and Part VI, Chapter 2 of the Hanford Facility RCRA Permit. The waste discharged to the basins originated in the 300 Area fuel fabrication facility and included solutions of chromic, hydrofluoric, nitric, and sulfuric acids that had been neutralized. The waste solutions contained various metallic and radioactive constituents (e.g., chromium, technetium-99, and uranium). Between 1985 and 1996, the remaining waste was removed, the facility was demolished, and the underlying contaminated soil was removed and replaced with clean fill.

The regulations in WAC 173-303-645(11) require corrective action activities to reduce contaminant concentrations in groundwater. The 183-H Solar Evaporation Basins Postclosure Plan (DOE/RL-97-48), which was incorporated into Part VI of the Hanford Facility RCRA Permit in February 1998, deferred further actions at the 183-H basins to the Comprehensive Environmental Response, Compensation, and Liability Act of 1980 (CERCLA) interim action for the 100-HR-3 Operable Unit (OU). The post-closure plan also requires monitoring to be conducted as described in the final status RCRA groundwater monitoring plan (Groundwater Monitoring Plan for the 183-H Solar Evaporation Basins [PNNL-11573]).

The concentration limits established for the $183-\mathrm{H}$ groundwater plume are provided in Table 2-1. These concentration limits were applied during compliance monitoring to determine whether corrective action was necessary as required under WAC 173-303-645. No formal comparison of contaminant concentrations to these limits will be made during the period of interim remedial action.

Table 2-1. 183-H Basins Groundwater Plume Concentration Limits.

\begin{tabular}{|l|l|}
\hline \multicolumn{1}{|c|}{$\begin{array}{c}\text { Dangerous Waste } \\
\text { Constituents }\end{array}$} & \multicolumn{1}{c|}{$\begin{array}{c}\text { Concentration } \\
\text { Limit }\end{array}$} \\
\hline Chromium (total; filtered sample) & $\begin{array}{l}122 \mu \mathrm{g} / \mathrm{L}-\text { local background when compliance monitoring plan } \\
\text { written (1996); upgradient sources }\end{array}$ \\
\hline Nitrate & $\left.45 \mathrm{mg} / \mathrm{L}-\mathrm{DWS}(\text { as NO})_{3}\right)$ \\
\hline Other 183-H Waste Indicators & $900 \mathrm{pCi} / \mathrm{L}-\mathrm{DWS}$ \\
\hline Technetium-99 & $20 \mu \mathrm{g} / \mathrm{L}-$ proposed DWS when monitoring plan written $(1996)$ \\
\hline Uranium (total; chemical analysis)
\end{tabular}

DWS $=$ drinking water standard 


\section{$2.1 \quad$ 100-HR-3 INTERIM REMEDIAL ACTION}

The interim remedial action applies to the 100-HR-3 Groundwater OU, which is under the authority of a CERCLA Record of Decision (ROD) (Record of Decision for the USDOE Hanford 100-HR-3 and 100-KR-4 Operable Units Interim Remedial Actions [EPA/ROD/R10-96/134]). Groundwater in the 100-H Area is pumped from extraction wells, treated to remove chromium, and injected back into the aquifer. The objective of the interim remedial action is to reduce the amount of chromium entering the Columbia River, where it is a potential hazard to the ecosystem. The active extraction and injection wells are illustrated in Figure 2-1.

Groundwater is sampled to monitor the performance of the interim remedial action and to monitor the entire 100-HR-3 OU (Interim Action Monitoring Plan for the 100-HR-3 and 100-KR-4 Operable Units [DOE/RL-96-90]). The CERCLA monitoring is coordinated with RCRA monitoring.

The pump-and-treat system may be shut down when concentrations of hexavalent chromium are below $22 \mu \mathrm{g} / \mathrm{L}$ in the extraction and compliance wells (as specified in the Remedial Design and Remedial Action Work Plan for the 100-HR-3 and 100-KR-4 Groundwater Operable Units' Interim Action [DOE/RL-96-84]) and data indicate that the concentration will remain below that value. The system may also be shut down if it proves ineffective or if a better treatment technique is found.

\subsection{RCRA GROUNDWATER MONITORING PROGRAM FOR 183-H BASINS}

During the period of time that the CERCLA interim remedial action for chromium is extracting groundwater, RCRA corrective action monitoring will continue to evaluate new analytical results relative to concentration limits stated in the RCRA Permit. Additionally, fluoride results will be evaluated relative to previously established trends and the drinking water standard (DWS) for fluoride (Part VI, Post-Closure Unit 2 of the Hanford Facility RCRA Permit; Permit No. WA 7890008967).

The RCRA groundwater monitoring network includes wells 199-H4-3, 199-H4-8, 199-H4-12A, and 199-H4-12C (see Figure 2-1). The conditions in Part VI, Post-Closure Unit 2 of the Hanford Facility RCRA Permit provide for groundwater sample collection annually in these wells (generally in November). No samples were collected for RCRA during the reporting period. However, all four wells were sampled for the 100-HR-3 interim action for hexavalent chromium. Two wells also were sampled for nitrate, technetium-99, and uranium.

Well 199-H4-12A has been an extraction well since 1997, and well 199-H4-3 was converted to an extraction well in August 2005. Well 199-H4-8 has been part of the RCRA network since 2006; it replaced well 199-H4-7, which was converted to an injection well for the 100-HR-3 pump-and-treat system. Wells 199-H4-3, 199-H4-8, and 199-H4-12A are completed at the top of the unconfined aquifer. Well 199-H4-12C is located adjacent to well 199-H4-12A and is completed deeper in the Ringold Formation. 
Figure 2-1. Monitoring Well Locations for 183-H (116-H-6) Basins.

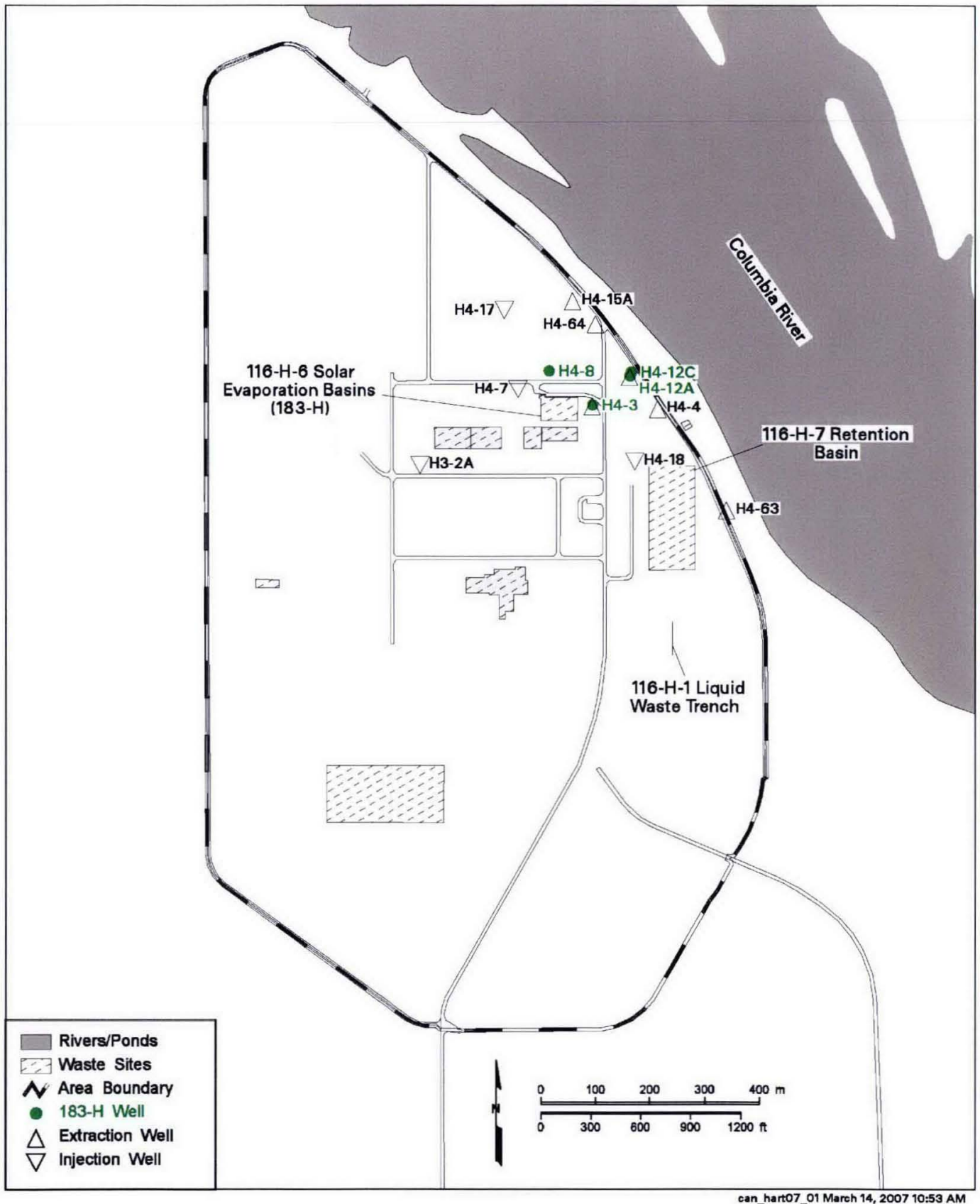

\subsection{CONTAMINANT TRENDS FOR 183-H BASINS}

This section discusses the concentrations of chromium, nitrate, technetium- 99 , and uranium in the groundwater. Results of samples collected during the reporting period (all collected for the CERCLA interim remedial action) are presented in Table 2-2, and pertinent results are discussed in the following paragraphs. 
SGW-39299, Rev. 0

Table 2-2. Groundwater Data for 183-H Basins, January Through June 2008.

\begin{tabular}{|c|c|c|c|c|c|}
\hline Well & Date & $\begin{array}{c}\text { Hexavalent } \\
\text { Chromium } \\
(\mu g / L)\end{array}$ & $\begin{array}{c}\text { Nitrate } \\
\text { (mg/L) }\end{array}$ & $\begin{array}{c}\text { Te-99 } \\
(\mathbf{p C i} / \mathrm{L})\end{array}$ & $\begin{array}{c}\text { Uranium } \\
(\mu \mathrm{g} / \mathrm{L})\end{array}$ \\
\hline \multicolumn{2}{|c|}{ Concentration limit $^{\mathrm{a}}$} & 122 & 45 & 900 & 20 \\
\hline \multirow{9}{*}{ 199-H4-12A } & $1 / 2 / 08$ & 19 & & & \\
\hline & $2 / 4 / 08$ & 24 & & & \\
\hline & $2 / 6 / 08$ & 14 & $24.3 \mathrm{D}$ & 14 & 7.63 \\
\hline & $2 / 6 / 08$ & 20 & & & \\
\hline & $3 / 3 / 08$ & 15 & & & \\
\hline & $4 / 1 / 08$ & 16 & & & \\
\hline & $5 / 5 / 08$ & 18 & & & \\
\hline & $6 / 2 / 08$ & 2 & & & \\
\hline & $6 / 30 / 08$ & 5 & & & \\
\hline 199-H4-12C & $6 / 2 / 08$ & 81 & & & \\
\hline \multirow{9}{*}{ 199-H4-3 } & $1 / 2 / 08$ & 10 & & & \\
\hline & $2 / 4 / 08$ & 13 & & & \\
\hline & $2 / 6 / 08$ & 11 & $35.5 \mathrm{D}$ & 28 & 7.98 \\
\hline & $2 / 6 / 08$ & 5 & & & \\
\hline & $3 / 3 / 08$ & 8 & & & \\
\hline & $4 / 1 / 08$ & 11 & & & \\
\hline & $5 / 5 / 08$ & 6 & & & \\
\hline & $6 / 2 / 08$ & 9 & & & \\
\hline & $6 / 30 / 08$ & 27 & & & \\
\hline 199-H4-8 & $6 / 2 / 08$ & $2.9 \mathrm{~B}$ & & & \\
\hline
\end{tabular}

${ }^{a}$ Concentration limits defined in Part VI, Post-Closure Unit 2 of the Hanford Facility RCRA Permit (Dangerous Waste Portion of the Resource Conservation and Recovery Act Permit for the Treatment, Storage, and Disposal of Dangerous Waste [Permit No. WA 7890008967]).

$\mathrm{B}=$ less than contract-required detection limit but greater than method detection limit

$\mathrm{D}=$ sample diluted for analysis; result corrected for dilution

Hexavalent chromium concentrations ranged from 2 to $81 \mu \mathrm{g} / \mathrm{L}$. The highest concentrations continued to be in deep well 199-H4-12C; however, the levels are declining gradually (Figure 2-2). This well consistently has elevated concentrations of chromium without any other $183-\mathrm{H}$ basins co-contaminants; thus, it appears that the chromium in this well has come from another source.

Chromium levels rose briefly in well 199-H4-3 in the summers of 2006 and 2007, and to a lesser extent, in $2008(27 \mu \mathrm{g} / \mathrm{L}$ in June 2008) (see Figure 2-2). This extraction well is nearest to the former $183-\mathrm{H}$ basins and historically had the highest chromium concentrations in the $100-\mathrm{H}$ Area. In extraction well 199-H4-12A chromium levels were stable at approximately $20 \mu \mathrm{g} / \mathrm{L}$ until June 2008 , when they dropped to 5 and $2 \mu \mathrm{g} / \mathrm{L}$. Levels are low $(2.9 \mu \mathrm{g} / \mathrm{L})$ in well 199-H4-8. Chromium results from all four wells were far below the $122 \mu \mathrm{g} / \mathrm{L}$ concentration limit (see Table 2-2). 
Figure 2-2. Hexavalent Chromium Concentrations in 183-H Wells.
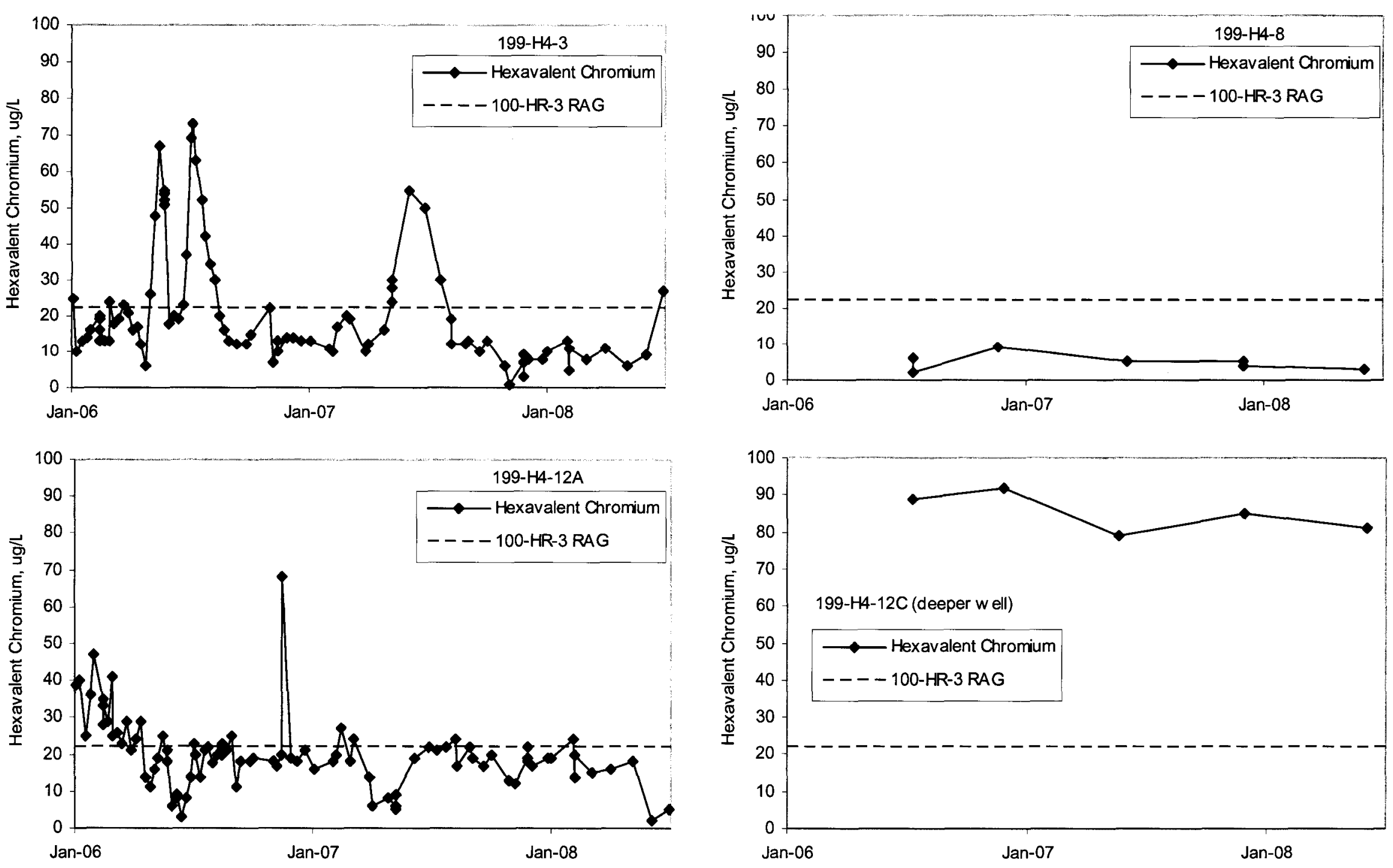
During the reporting period, nitrate was analyzed in wells $199-\mathrm{H} 4-3(35.5 \mathrm{mg} / \mathrm{L})$ and 199-H4-12A (24.3 mg/L). Concentrations have declined since 2006 (Figure 2-3).

Technetium-99 and uranium concentrations remained low during the reporting period in the two wells sampled for those constituents (Table 2-2; Figures 2-4 and 2-5). The concentration limits for these constituents are $900 \mathrm{pCi} / \mathrm{L}$ and $20 \mu \mathrm{g} / \mathrm{L}$, respectively.

Figure 2-3. Nitrate Concentrations in 183-H Monitoring Wells Sampled During the Reporting Period.
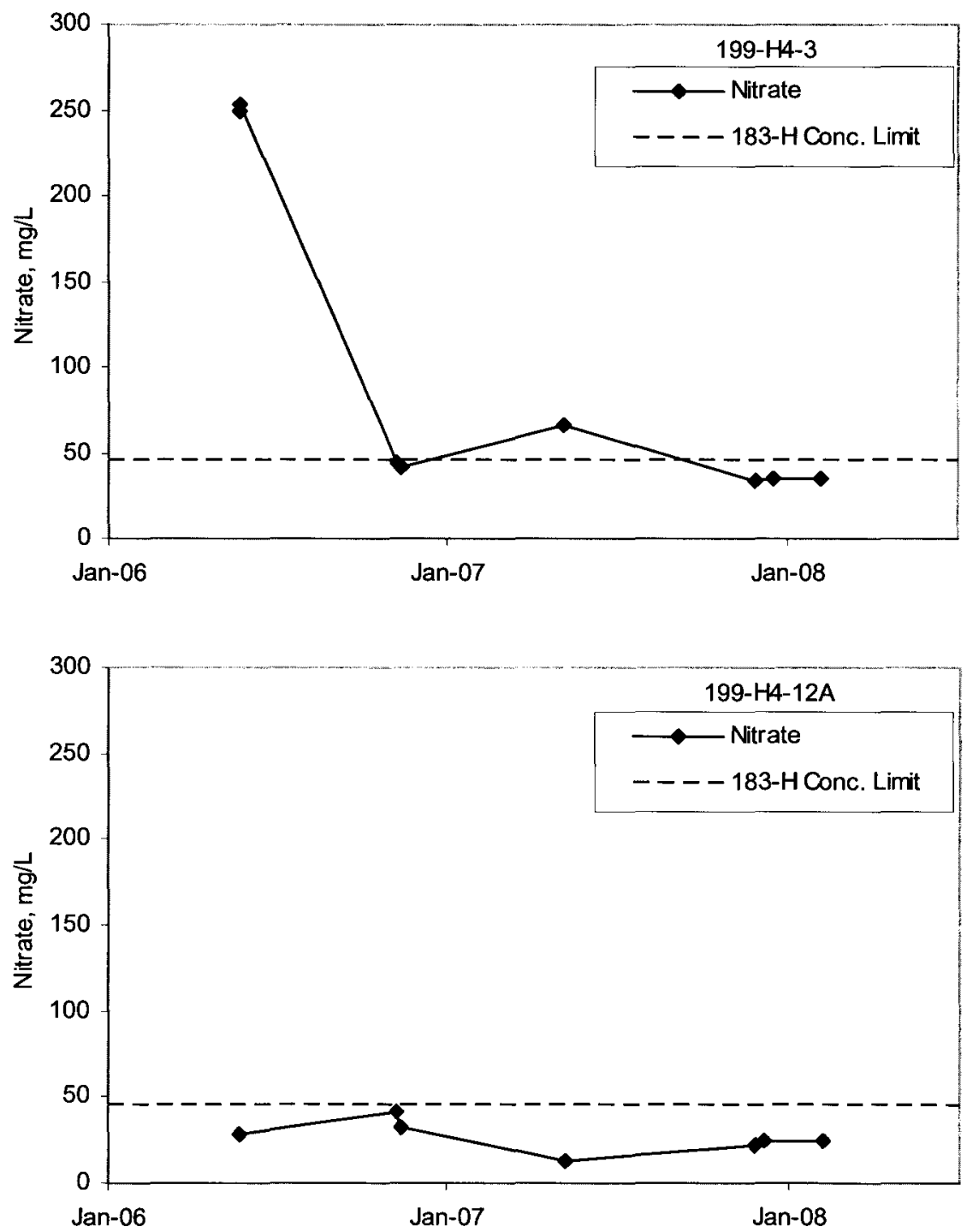
SGW-39299, Rev. 0

Figure 2-4. Technetium-99 Concentrations in 183-H Monitoring Wells Sampled During the Reporting Period.
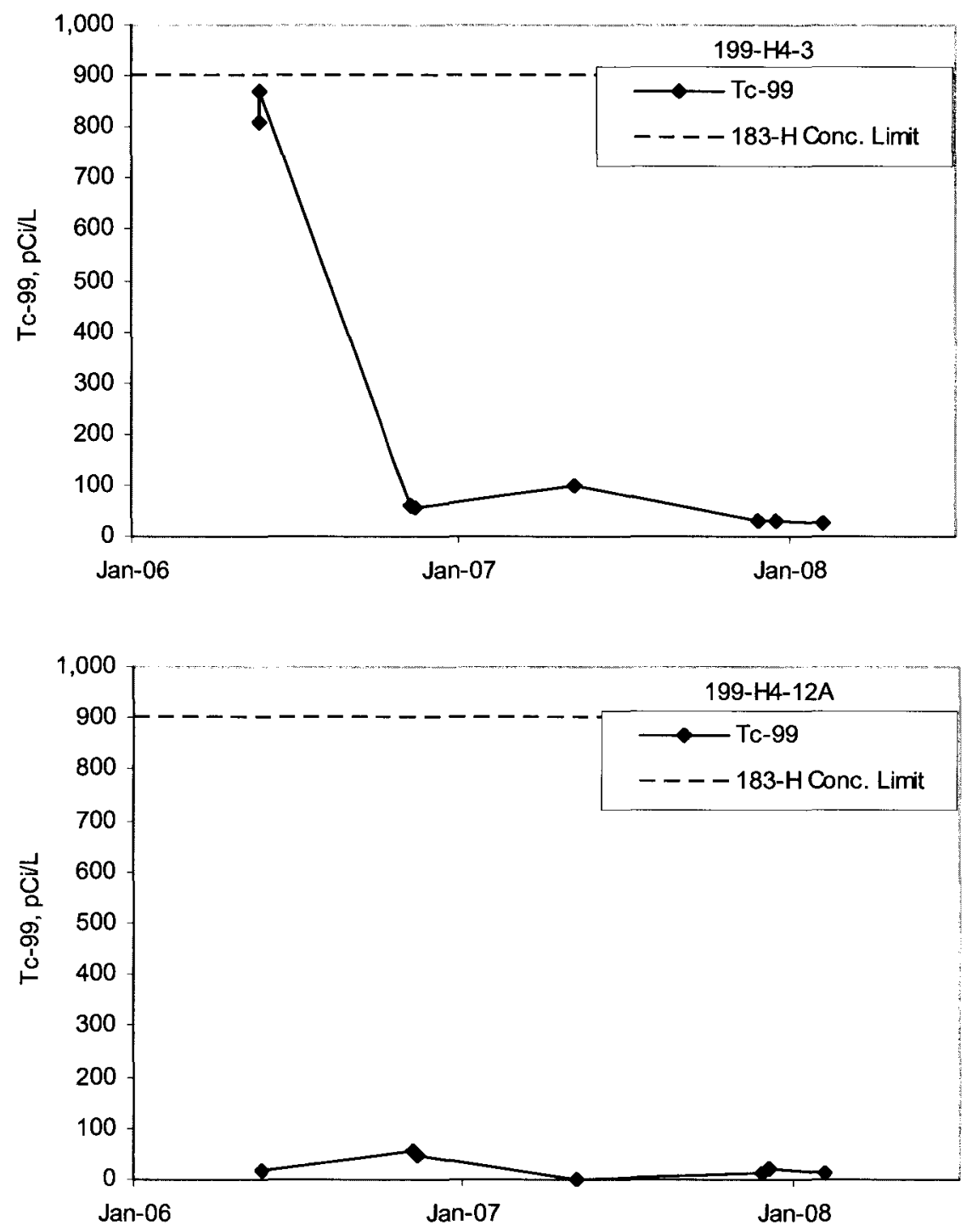
Figure 2-5. Uranium Concentrations in 183-H Monitoring Wells Sampled During the Reporting Period.
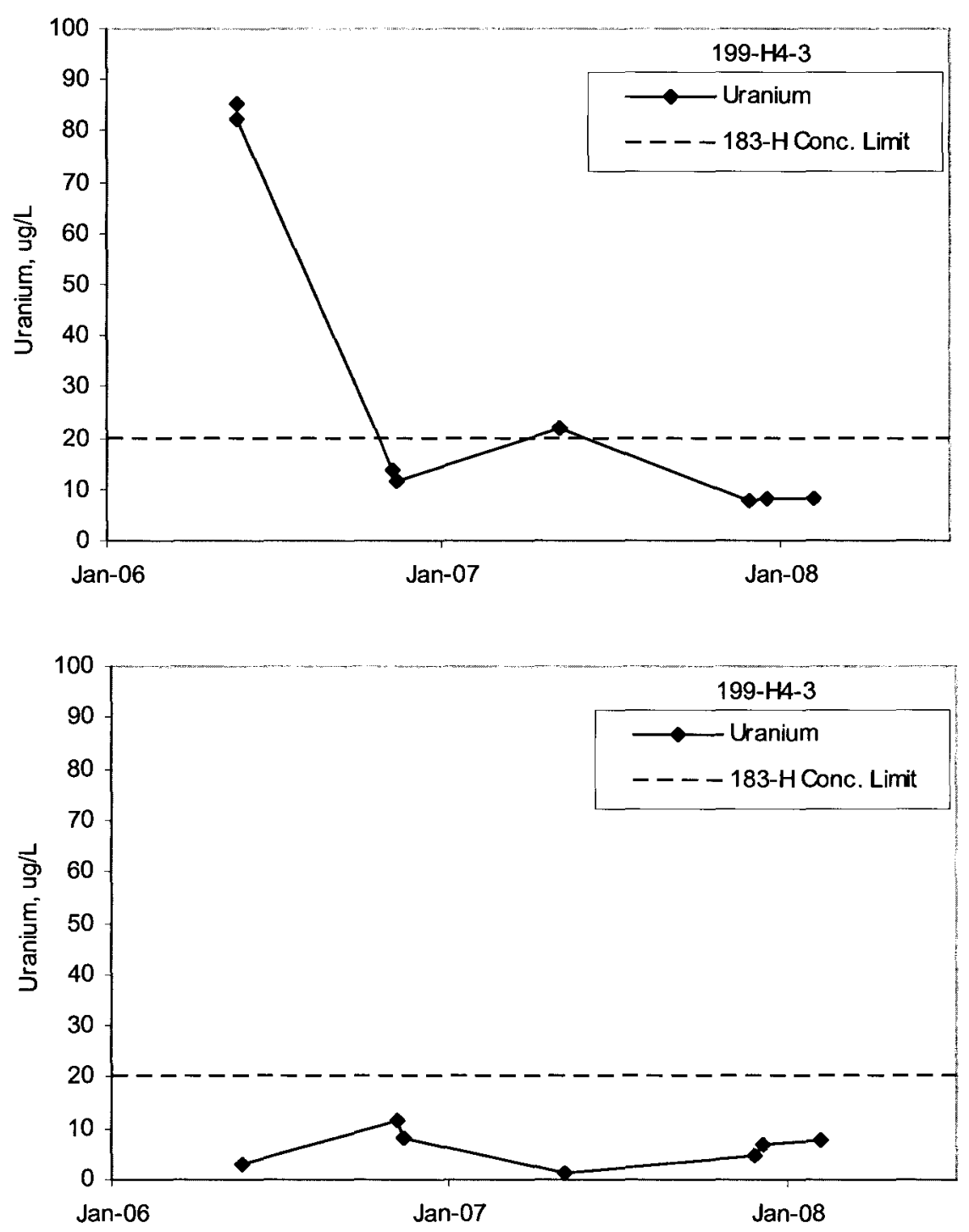

\section{$2.4 \quad$ 183-H BASINS CONCLUSIONS}

The current objective of RCRA corrective action monitoring is simply to track trends, not to determine the effectiveness of the interim remedial action. Although there is short-term variability in contaminant concentrations, trends are downward, or low and stable. The groundwater monitoring program described in Part VI, Post-Closure Unit 2 of the Hanford Facility RCRA Permit (see Table 2-1) remains adequate for the objective of tracking trends during the period of the CERCLA interim remedial action. 


\subsection{AREA PROCESS TRENCHES}

The 300 Area process trenches are a RCRA treatment, storage, and/or disposal unit in the Hanford Facility RCRA Permit. From 1975 to 1994, the trenches received effluent discharges of dangerous mixed waste from fuel fabrication and research laboratories in the 300 Area. Groundwater monitoring at the 300 Area process trenches is conducted in accordance with WAC 173-303-645(11), "Corrective Action Program," and Part VI, Chapter 1 of the Hanford Facility RCRA Permit (Permit No. WA7890008967). The 300 Area Process Trenches Modified Closure Plan and Part A, Form 3 (DOE/RL-93-73), portions of which are incorporated into the Hanford Facility RCRA Permit, indicates that groundwater remediation is deferred to the CERCLA 300-FF-5 Groundwater OU.

The objective of groundwater monitoring during the corrective action period is to demonstrate the effectiveness of the corrective action program by examining the trend of the groundwater constituents of interest to confirm that they are attenuating naturally, as expected by the CERCLA ROD for the 300-FF-5 OU (Declaration of the Record of Decision for the 300-FF-1 and 300-FF-5 Operable Units [EPA et al. 1996]). The 300 Area process trenches were closed under a modified closure/post-closure plan (DOE/RL-93-73) and remain in the groundwater corrective action program because groundwater contamination continues to exceed groundwater quality criteria (Federal drinking water standards [DWSs]). Groundwater monitoring will continue for 30 years during the post-closure monitoring period.

The concentration limits established for the 300 Area process trenches are provided in Table 3-1. These limits were applied during compliance monitoring to determine whether corrective action was necessary as required in accordance with WAC 173-303-645.

\subsection{RCRA GROUNDWATER MONITORING PROGRAM FOR 300 AREA PROCESS TRENCHES}

The groundwater monitoring network for the 300 Area process trenches (Groundwater Monitoring Plan for the 300 Area Process Trenches [WHC-SD-EN-AP-185]) includes four well pairs (Figure 3-1). Each of the well pairs has one shallow and one deep well. The shallow wells are screened at the water table, and the deep wells are screened at the bottom of the unconfined aquifer (above the lacustrine and over-bank deposits of the Ringold Lower Mud Unit). One of the pairs is upgradient, and the other three pairs are downgradient. The constituents of interest are the volatile organic compounds cis-1,2-dichloroethene, trichloroethene (TCE), and tetrachloroethene (PCE), and the non-RCRA-regulated constituent uranium. Sampling frequency is semi-annual, but during each semi-annual sampling period the wells are sampled four times (monthly intervals). As a result, the wells are sampled during the months of December, January, February, March, and June, July, August, and September. Groundwater samples are analyzed for the constituents of interest. Data from wells other than the 300 Area process trenches network (300-FF-5 OU wells) are used as supplementary information to construct larger-scale water-table and uranium-concentration maps that extend beyond the area of the 300 Area process trenches network.

During the January to June 2008 reporting period, all of the 300 Area process trenches network wells were sampled, but sampling was delayed until July 1 in three wells. Data from the delayed samples are discussed in this document even though they were collected outside the reporting 
period. The wells also were sampled once in April for the 300-FF-5 OU. Uranium data from that sampling event are included in Table 3-1 and trend plots.

Table 3-1. Concentration Limits for 300 Area Process Trenches.

\begin{tabular}{|l|l|}
\hline \multicolumn{1}{|c|}{$\begin{array}{c}\text { Dangerous Waste } \\
\text { Constituents }\end{array}$} & \multicolumn{1}{c|}{$\begin{array}{c}\text { Concentration } \\
\text { Limit }\end{array}$} \\
\hline cis-1,2-dichloroethene & $70 \mu \mathrm{g} / \mathrm{L}$-- DWS \\
\hline Trichloroethene (TCE) & $5 \mu \mathrm{g} / \mathrm{L}$-- DWS \\
\hline Other 300 Area Process Trenches Waste Indicators \\
\hline Uranium (total; chemical analysis) & $20 \mu \mathrm{g} / \mathrm{L}$ - proposed DWS when monitoring plan written (1996) \\
\hline
\end{tabular}

DWS $=$ drinking water standard

\subsection{CONTAMINANT TRENDS FOR 300 AREA PROCESS TRENCHES}

This section discusses concentrations of uranium, cis-1,2-dichloroethene, TCE, and PCE (the constituents of interest) in the well network during the reporting period. Table 3-2 lists the analytical results for each contaminant of interest in each well of the monitoring network.

\subsubsection{Uranium}

A persistent uranium plume continues to underlie a large portion of the 300 Area. Uranium was detected in five of the eight network wells during the reporting period. It was not detected at 399-1-10B, 399-1-17B, and 399-1-18B. Uranium concentrations exceeded the concentration limit $(20 \mu \mathrm{g} / \mathrm{L})$ at wells 399-1-10A, 399-1-16A, and 399-1-17A. These three downgradient wells are screened at the water table. The highest concentration reported in the network wells was $116 \mu \mathrm{g} / \mathrm{L}$ at well 399-1-17A in a sample collected in June 2008.

Uranium concentration trends at wells 399-1-10A and 399-1-16A (Figures 3-2 and 3-3, respectively), declined in July 2008. This trend is typical for these wells, which are located near the Columbia River. When river stage is high, as it was in June and early July 2008, the uranium concentrations decrease due to mixing with river water.

The uranium concentration at well 399-1-17A, which is located farther from the river, increased in July (Figure 3-4). At inland locations in the 300 Area, uranium concentrations typically increase during periods of high water table conditions. This may be caused by the groundwater mobilizing uranium that is sequestered in the lower portion of the vadose zone. Response of the water table and uranium concentration in the 300 Area is described in detail in previous semi-annual reports on the RCRA 300 Area process trenches and in annual reports of the groundwater performance assessment project (e.g., Hanford Site Groundwater Monitoring for Fiscal Year 2007 [DOE/RL-2008-01]). 
Figure 3-1. Locations of Wells in the 300 Area Process Trenches Monitoring Network.

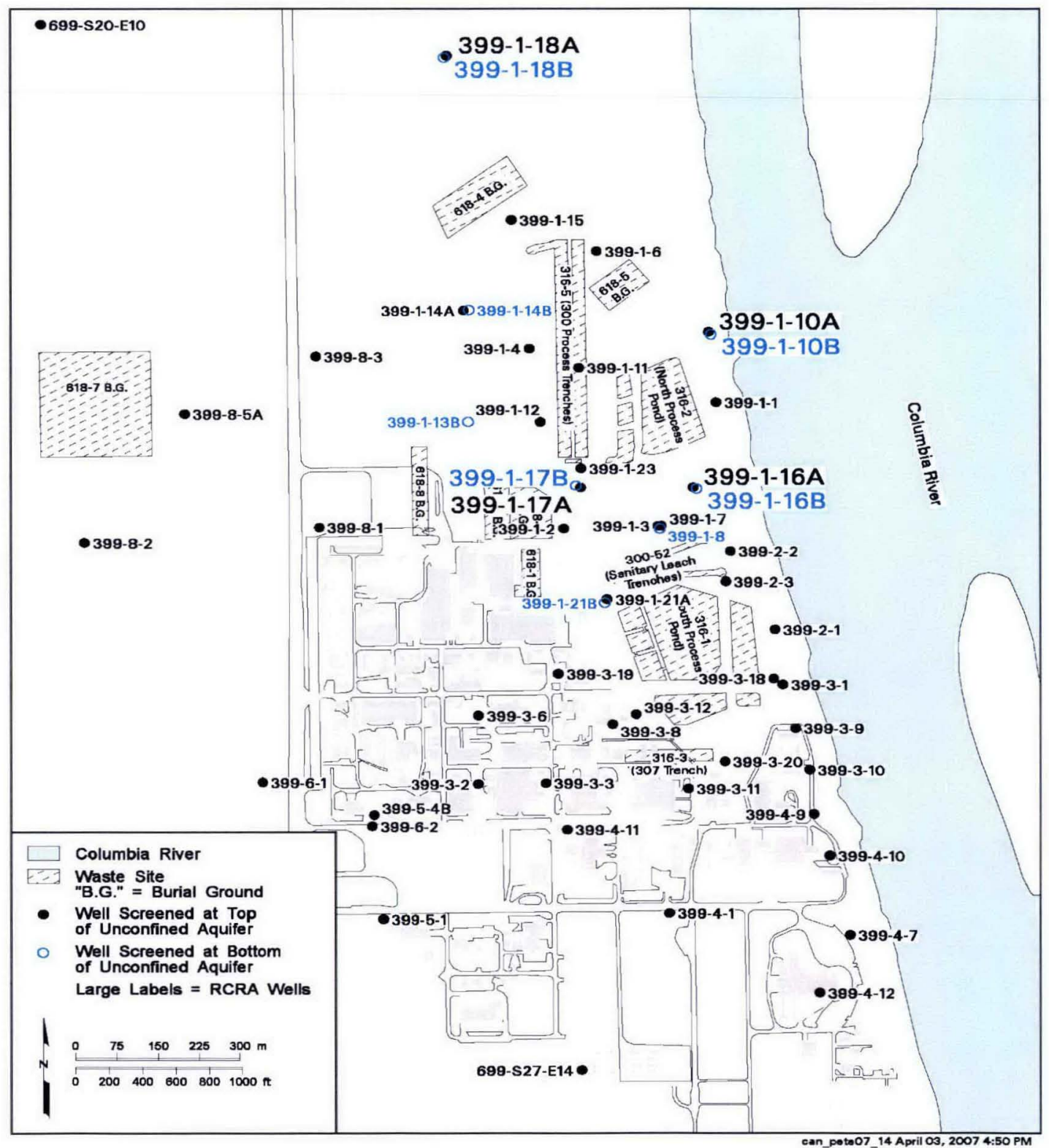

NOTE: This figure is from Groundwater Monitoring Plan for the 300 Area Process Trenches (WHC-SD-EN-AP-185). The four well pairs of the 300 Area process trenches network have larger labels. 
Table 3-2. Groundwater Data for 300 Area Process Trenches, January Through June 2008. (2 sheets)

\begin{tabular}{|c|c|c|c|c|c|c|c|c|c|}
\hline \multirow{2}{*}{$\begin{array}{c}\text { Well } \\
399-1-10 \mathrm{~A}\end{array}$} & \multirow{2}{*}{$\begin{array}{c}\text { Date } \\
1 / 11 / 08\end{array}$} & \multicolumn{2}{|c|}{$\begin{array}{c}\text { cis-1,2-DCE } \\
(\mu g / L)\end{array}$} & \multicolumn{2}{|c|}{$\begin{array}{c}\text { Tetrachloro- } \\
\text { ethene } \\
(\mu \mathrm{g} / \mathrm{L})\end{array}$} & \multicolumn{2}{|c|}{$\begin{array}{c}\text { Trichloroethene } \\
\qquad(\mu \mathrm{g} / \mathrm{L})\end{array}$} & \multicolumn{2}{|c|}{$\begin{array}{c}\text { Uranium } \\
(\mu \mathrm{g} / \mathrm{L})\end{array}$} \\
\hline & & 1 & $\mathrm{U}$ & 1 & $\mathrm{U}$ & 1 & $\mathrm{U}$ & 34.2 & \\
\hline $399-1-10 A$ & $2 / 8 / 08$ & 1 & $\mathrm{U}$ & 1 & $\mathrm{U}$ & 1 & $\mathrm{U}$ & 37.8 & \\
\hline $399-1-10 A$ & $3 / 16 / 08$ & 1 & $\mathrm{U}$ & 1 & $\mathrm{U}$ & 1 & $\mathrm{U}$ & 41.3 & \\
\hline $399-1-10 A$ & $4 / 1 / 08$ & & & & & & & 40.2 & \\
\hline $399-1-10 \mathrm{~A}$ & $7 / 1 / 08$ & 1 & $\mathrm{U}$ & 1 & $\mathrm{U}$ & 1 & $\mathrm{U}$ & 16.6 & \\
\hline $399-1-10 A$ & $7 / 1 / 08$ & 1 & $\mathrm{U}$ & 1 & $\mathrm{U}$ & 1 & $\mathrm{U}$ & 15.8 & \\
\hline $399-1-10 \mathrm{~B}$ & $1 / 11 / 08$ & 1 & $\mathrm{U}$ & 1 & $\mathrm{U}$ & 1 & $\mathrm{U}$ & 0.05 & $\mathrm{U}$ \\
\hline $399-1-10 \mathrm{~B}$ & $2 / 8 / 08$ & 1 & $\mathrm{U}$ & 1 & $\mathrm{U}$ & 1 & $\mathrm{U}$ & 0.05 & $\mathrm{U}$ \\
\hline $399-1-10 \mathrm{~B}$ & $3 / 16 / 08$ & 1 & $\mathrm{U}$ & 1 & $\mathrm{U}$ & 1 & $\mathrm{U}$ & 0.05 & $\mathrm{U}$ \\
\hline $399-1-10 \mathrm{~B}$ & $7 / 1 / 08$ & 1 & $\mathrm{U}$ & 1 & $\mathrm{U}$ & 1 & $\mathrm{U}$ & 0.08 & \\
\hline $399-1-16 A$ & $1 / 11 / 08$ & 1 & $\mathrm{U}$ & 1 & $\mathrm{U}$ & 1 & $\mathrm{U}$ & 68.4 & \\
\hline $399-1-16 A$ & $1 / 11 / 08$ & 1 & $\mathrm{U}$ & 1 & $\mathrm{U}$ & 1 & $\mathrm{U}$ & 69.8 & \\
\hline $399-1-16 A$ & $2 / 8 / 08$ & 1 & $\mathrm{U}$ & 1 & $\mathrm{U}$ & 1 & $\mathrm{U}$ & 69.8 & \\
\hline $399-1-16 \mathrm{~A}$ & $3 / 16 / 08$ & 1 & $\mathrm{U}$ & 1 & $\mathrm{U}$ & 1 & $\mathrm{U}$ & 70.8 & \\
\hline $399-1-16 A$ & $4 / 1 / 08$ & & & & & & & 66.9 & \\
\hline $399-1-16 \mathrm{~A}$ & $7 / 1 / 08$ & 1 & $\mathrm{U}$ & 1 & $\mathrm{U}$ & 1 & $\mathrm{U}$ & 37.1 & \\
\hline $399-1-16 \mathrm{~B}$ & $1 / 11 / 08$ & 140 & & 1 & $\mathrm{U}$ & 1 & $\mathrm{U}$ & 10.9 & \\
\hline $399-1-16 \mathrm{~B}$ & $2 / 8 / 08$ & 190 & & 1 & $\mathrm{U}$ & 1 & $\mathrm{U}$ & 12.1 & \\
\hline $399-1-16 \mathrm{~B}$ & $3 / 16 / 08$ & 180 & & 1 & $\mathrm{U}$ & 1 & $\mathrm{U}$ & 15.8 & \\
\hline $399-1-16 B$ & $6 / 22 / 08$ & 170 & & 1 & $\mathrm{U}$ & 1 & $\mathrm{U}$ & 10.9 & \\
\hline $399-1-16 \mathrm{~B}$ & $6 / 22 / 08$ & 170 & & 1 & $\mathrm{U}$ & 1 & $\mathrm{U}$ & 12 & \\
\hline $399-1-17 A$ & $1 / 11 / 08$ & 1 & $\mathrm{U}$ & 1 & $\mathrm{U}$ & 1 & $\mathrm{U}$ & 36 & \\
\hline $399-1-17 \mathrm{~A}$ & $2 / 8 / 08$ & 1 & $\mathrm{U}$ & 1 & $\mathrm{U}$ & 1 & $\mathrm{U}$ & 41.5 & \\
\hline $399-1-17 \mathrm{~A}$ & $2 / 8 / 08$ & 1 & $\mathrm{U}$ & 1 & $\mathrm{U}$ & 1 & $\mathrm{U}$ & 40.2 & \\
\hline $399-1-17 A$ & $3 / 25 / 08$ & 1 & $\mathrm{U}$ & 1 & $\mathrm{U}$ & 1 & $\mathrm{U}$ & 48.9 & \\
\hline $399-1-17 A$ & $4 / 1 / 08$ & & & & & & & 51.7 & \\
\hline $399-1-17 A$ & $4 / 1 / 08$ & & & & & & & 51.3 & \\
\hline $399-1-17 A$ & $6 / 22 / 08$ & 1 & $\mathrm{U}$ & 1 & $\mathrm{U}$ & 1 & $\mathrm{U}$ & 116 & \\
\hline $399-1-17 \mathrm{~B}$ & $1 / 11 / 08$ & 1 & $\mathrm{U}$ & 1 & $\mathrm{U}$ & 1 & $\mathrm{U}$ & 0.05 & $\mathrm{U}$ \\
\hline
\end{tabular}


Table 3-2. Groundwater Data for 300 Area Process Trenches, January Through June 2008. (2 sheets)

\begin{tabular}{|c|c|c|c|c|c|c|c|c|c|}
\hline Well & Date & \multicolumn{2}{|c|}{$\begin{array}{c}\text { cis-1,2-DCE } \\
(\mu \mathrm{g} / \mathrm{L})\end{array}$} & $\begin{array}{c}\text { Tetrachloro- } \\
\text { ethene } \\
(\mu \mathrm{g} / \mathrm{L})\end{array}$ & \multicolumn{2}{c|}{$\begin{array}{c}\text { Trichloroethene } \\
(\mu \mathrm{g} / \mathrm{L})\end{array}$} & \multicolumn{2}{c|}{$\begin{array}{c}\text { Uranium } \\
(\mu \mathrm{g} / \mathrm{L})\end{array}$} \\
\hline $399-1-17 \mathrm{~B}$ & $2 / 8 / 08$ & 2 & $\mathrm{~J}$ & 1 & $\mathrm{U}$ & 1 & $\mathrm{U}$ & 0.05 & $\mathrm{U}$ \\
\hline $399-1-17 \mathrm{~B}$ & $3 / 25 / 08$ & 1 & $\mathrm{U}$ & 1 & $\mathrm{U}$ & 1 & $\mathrm{U}$ & 0.05 & $\mathrm{U}$ \\
\hline $399-1-17 \mathrm{~B}$ & $6 / 22 / 08$ & 1 & $\mathrm{U}$ & 1 & $\mathrm{U}$ & 1 & $\mathrm{U}$ & 0.05 & $\mathrm{U}$ \\
\hline $399-1-18 \mathrm{~A}$ & $2 / 21 / 08$ & 1 & $\mathrm{U}$ & 1 & $\mathrm{U}$ & 1 & $\mathrm{U}$ & 6.32 & \\
\hline $399-1-18 \mathrm{~A}$ & $3 / 16 / 08$ & 1 & $\mathrm{U}$ & 1 & $\mathrm{U}$ & 1 & $\mathrm{U}$ & 6.53 & \\
\hline $399-1-18 \mathrm{~A}$ & $6 / 22 / 08$ & 1 & $\mathrm{U}$ & 1 & $\mathrm{U}$ & 1 & $\mathrm{U}$ & 5.36 & \\
\hline $399-1-18 \mathrm{~B}$ & $1 / 25 / 08$ & 1 & $\mathrm{U}$ & 1 & $\mathrm{U}$ & 1 & $\mathrm{U}$ & 0.05 & $\mathrm{U}$ \\
\hline $399-1-18 \mathrm{~B}$ & $2 / 21 / 08$ & 1 & $\mathrm{U}$ & 1 & $\mathrm{U}$ & 1 & $\mathrm{U}$ & 0.05 & $\mathrm{U}$ \\
\hline $399-1-18 \mathrm{~B}$ & $3 / 16 / 08$ & 1 & $\mathrm{U}$ & 1 & $\mathrm{U}$ & 1 & $\mathrm{U}$ & 0.05 & $\mathrm{U}$ \\
\hline $399-1-18 \mathrm{~B}$ & $4 / 1 / 08$ & & & & & & & 0.05 & $\mathrm{U}$ \\
\hline $399-1-18 \mathrm{~B}$ & $6 / 22 / 08$ & 1 & $\mathrm{U}$ & 1 & $\mathrm{U}$ & 1 & $\mathrm{U}$ & 0.05 & $\mathrm{U}$ \\
\hline
\end{tabular}

\section{NOTES:}

1. Three wells were delayed unit July 1,2008 .

2. Bold values exceed concentration limits.

$\mathbf{J}=$ value is an estimate (close to detection limit

$\mathrm{U}=$ below detection limit

\subsubsection{Cis-1,2-Dichloroethene}

Cis-1,2-dichloroethene was detected at two wells in the 300 Area process trenches network during the reporting period (399-1-16B and 399-1-17B). The "B" wells are screened in the lower portion of the unconfined aquifer. Only well 399-1-16B had concentrations of cis-1,2-dichloroethene that exceeded the $70 \mu \mathrm{g} / \mathrm{L}$ concentration limit. The trend at well 399-1-16B (Figure 3-5) was relatively stable, around 140 to $170 \mu \mathrm{g} / \mathrm{L}$ from 2001 to 2004 , but increased in variability subsequently. The reason for the increased variability is unknown. The highest value during the reporting period was $190 \mu \mathrm{g} / \mathrm{L}$ for a sample collected in February 2008. The only other detection during the reporting period was an estimated $2 \mu \mathrm{g} / \mathrm{L}$ in well $399-1-17 \mathrm{~B}$ in February 2008.

\subsubsection{Trichloroethene}

During the reporting period, TCE $(5 \mu \mathrm{g} / \mathrm{L}$ concentration limit) was not detected at any of the samples that were taken. Wells 399-1-16A and 399-1-17A previously had TCE detections of $<1 \mu \mathrm{g} / \mathrm{L}$. Since fall 2007, the laboratory's detection limit has been $1 \mu \mathrm{g} / \mathrm{L}$. Well 399-1-16B previously had detections of 2 to $3 \mu \mathrm{g} / \mathrm{L}$ but since the fall of 2007 , concentrations have been $<1 \mu \mathrm{g} / \mathrm{L}$. 
SGW-39299, Rev. 0

Figure 3-2. Uranium Concentrations in Well 399-1-10A.

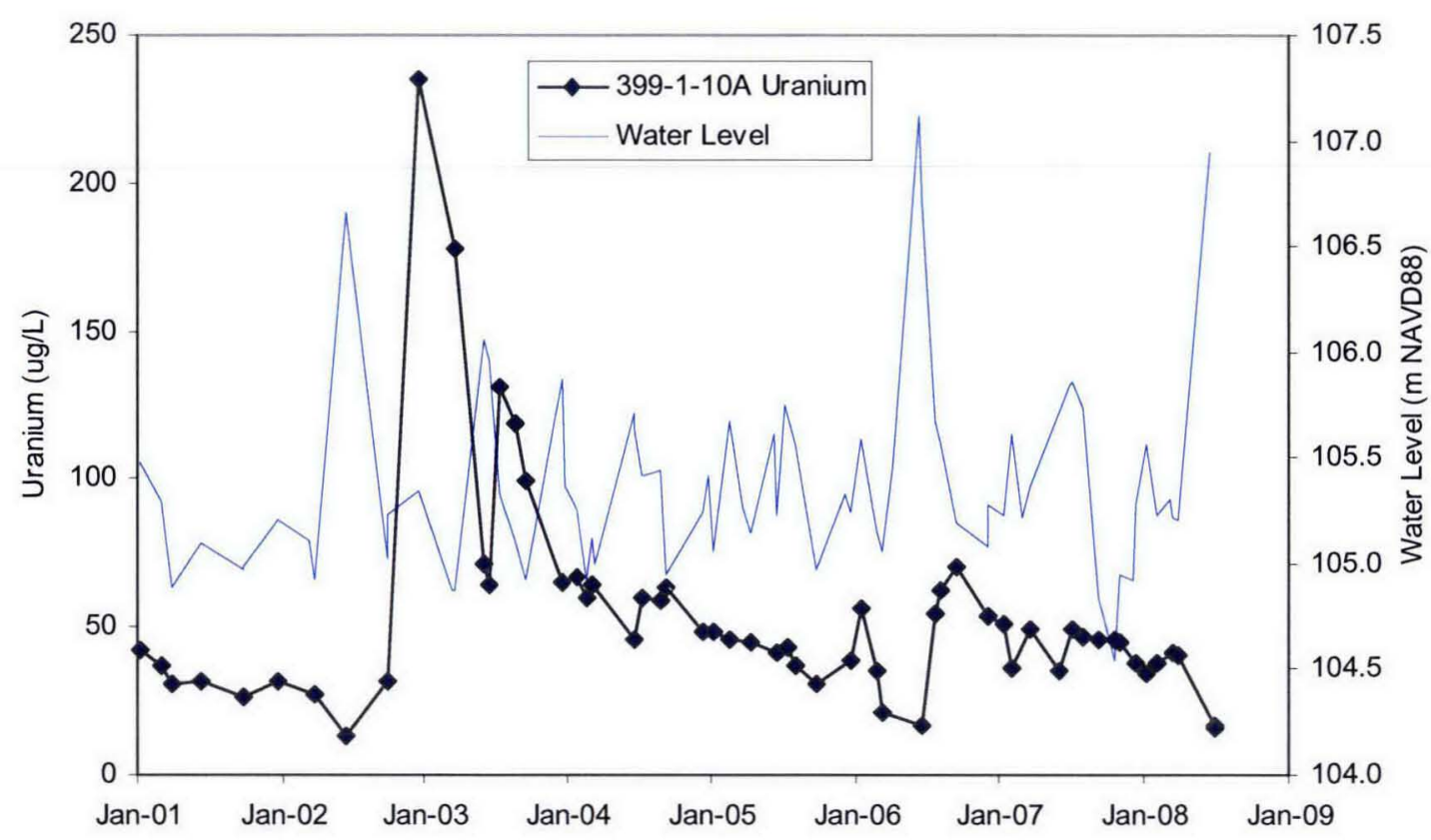

Figure 3-3. Uranium Concentrations in Well 399-1-16A.

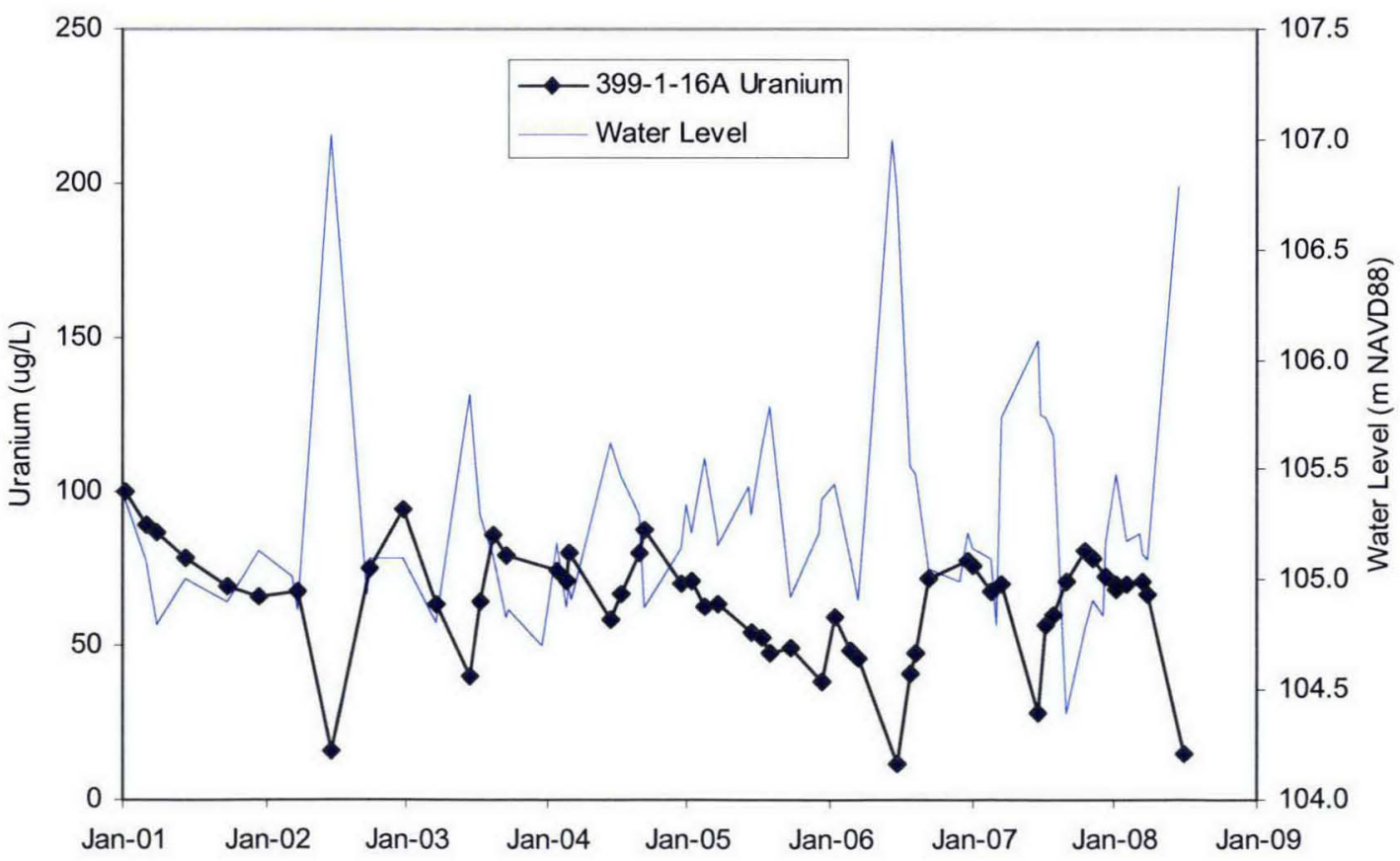


SGW-39299, Rev. 0

Figure 3-4. Uranium Concentrations in Well 399-1-17A.

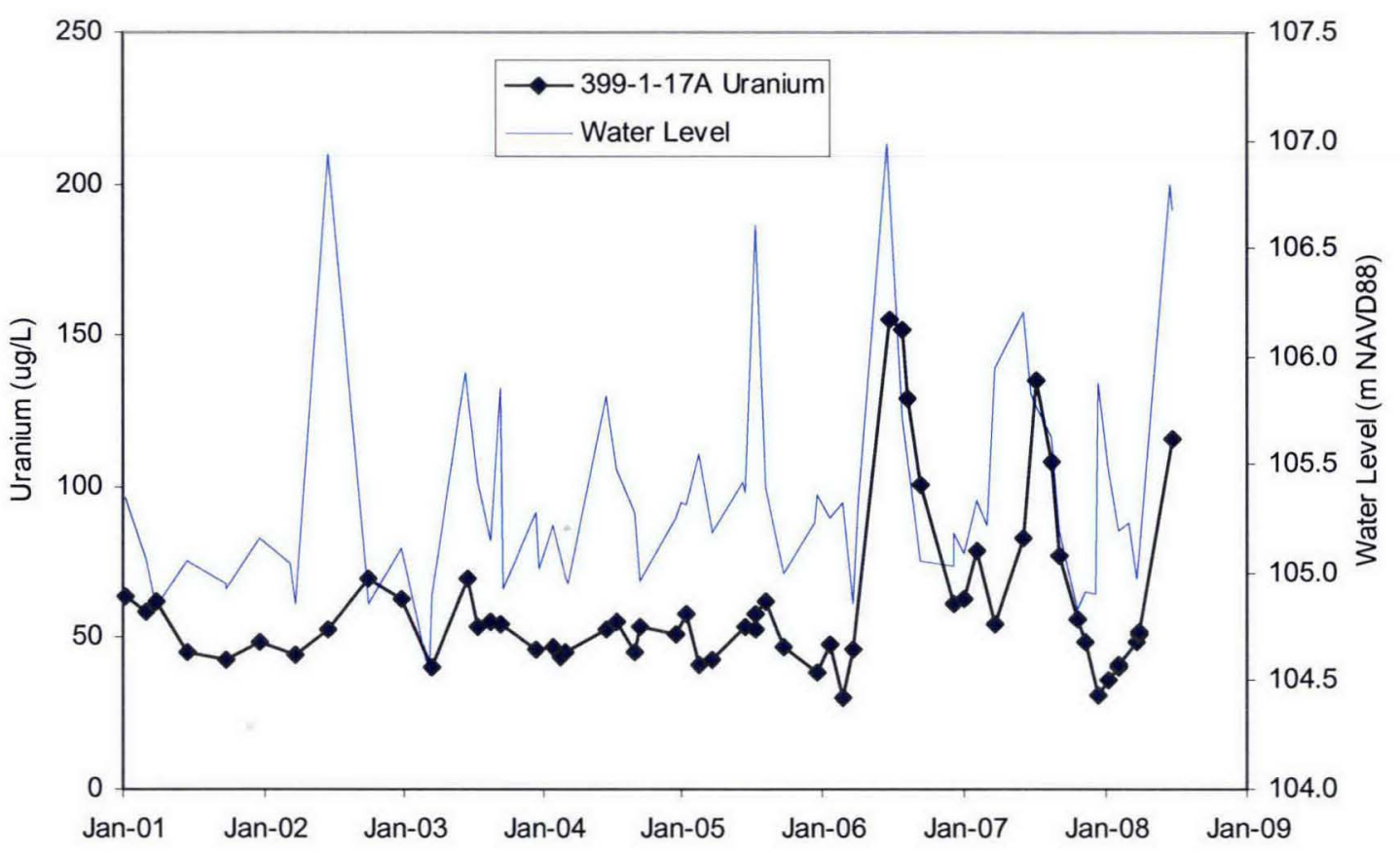

Figure 3-5. Cis-1,2-Dichloroethene Concentrations in Well 399-1-16B.

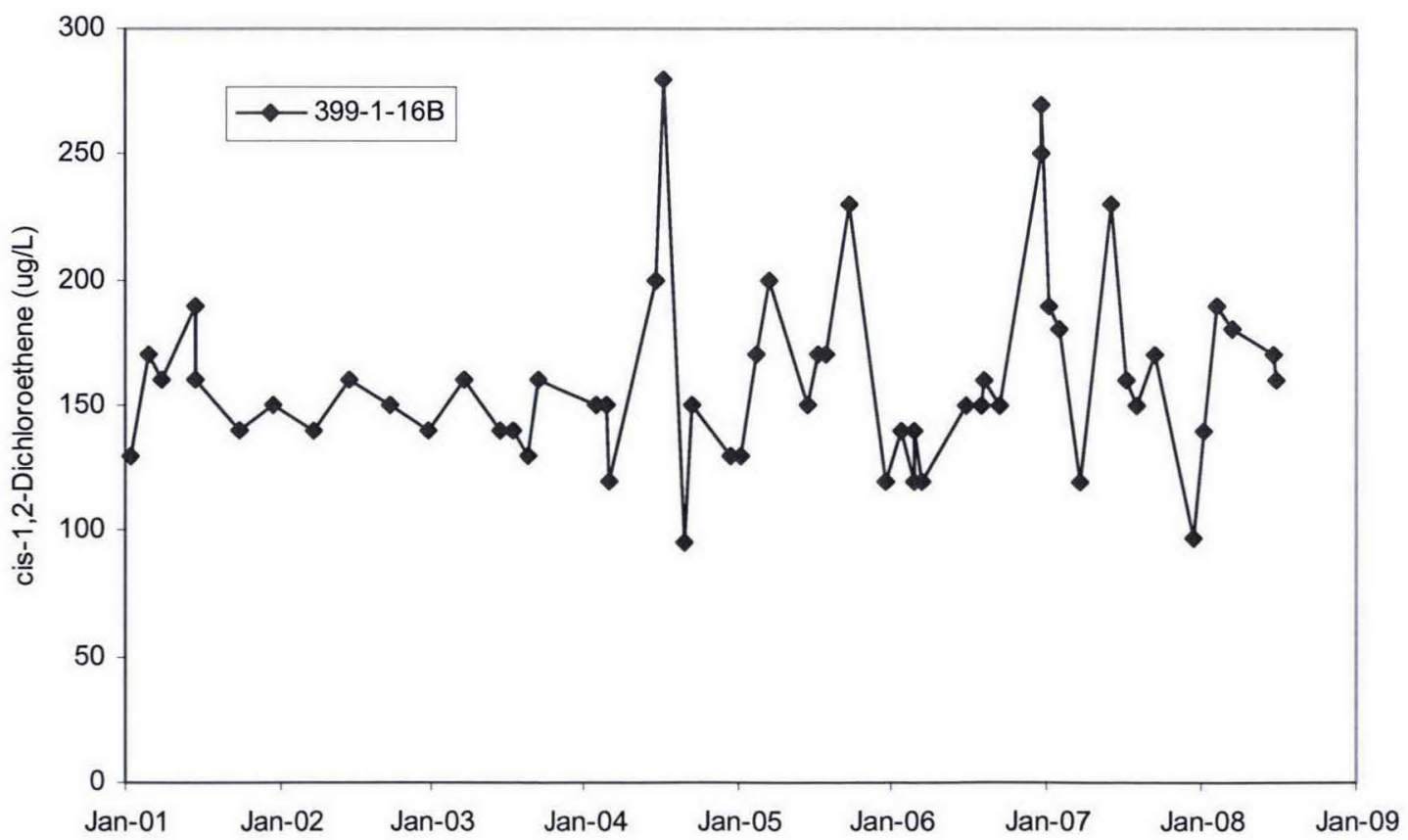


SGW-39299, Rev. 0

\subsubsection{Tetrachloroethene}

In recent years, PCE ( $5 \mu \mathrm{g} / \mathrm{L}$ DWS $)$ has occasionally been detected in the well network downgradient of the 300 Area process trenches. During the reporting period, it was not detected at levels above the method detection limit $(1 \mu \mathrm{g} / \mathrm{L})$.

\subsection{AREA PROCESS TRENCHES CONCLUSIONS}

The objective of groundwater monitoring at the 300 Area process trenches is to demonstrate the effectiveness of the corrective action program by examining the trend of the constituents of interest to confirm that they are attenuating naturally. Three wells downgradient of the 300 Area process trenches and screened at the water table continued to have uranium concentrations that exceeded the $30 \mu \mathrm{g} / \mathrm{L} \mathrm{DWS}$. The overall trends at these wells for the last few years are relatively stable, although occasionally there are temporary increases or decreases in uranium concentration. These variations are due to seasonal water table and river-level fluctuations that, in turn, alter groundwater chemistry and affect uranium adsorption in the aquifer. These relationships have been discussed in previous reports.

The concentration of cis-1,2-dichloroethene continued at levels above the DWS $(70 \mu \mathrm{g} / \mathrm{L})$ in one well (399-1-16B) and is not affected by river stage. The trend of this contaminant at well 399-1-16B has not attenuated as expected, and concentrations have generally fluctuated between about 120 and $240 \mu \mathrm{g} / \mathrm{L}$. The variability of cis-1,2-dichloroethene concentration at well 399-1-16B appears to have increased since 2005.

The TCE and PCE concentrations remained below detection limits during the reporting period. However, monitoring of these two volatile organics will continue because they remain constituents of interest in the groundwater monitoring plan. 


\subsection{REFERENCES}

Comprehensive Environmental Response, Compensation, and Liability Act of 1980, Public Law 96-510, as amended, 94 Stat. 2767, 42 U.S.C. 9601, et seq.

DOE/RL-93-73, 1995, 300 Area Process Trenches Modified Closure Plan and Part A, Form 3, Rev. 4, U.S. Department of Energy, Richland Operations Office, Richland, Washington.

DOE/RL-96-84, 2003, Remedial Design and Remedial Action Work Plan for the 100-HR-3 and 100-KR-4 Groundwater Operable Units' Interim Action, Rev. 0-A, U.S. Department of Energy, Richland Operations Office, Richland, Washington.

DOE/RL-96-90, 1997, Interim Action Monitoring Plan for the 100-HR-3 and 100-KR-4 Operable Units, Rev. 0, U.S. Department of Energy, Richland Operations Office, Richland, Washington.

DOE/RL-97-48, 1997, 183-H Solar Evaporation Basins Postclosure Plan, Rev. 0, U.S. Department of Energy, Richland Operations Office, Richland, Washington.

DOE/RL-2008-1, 2008, Hanford Site Groundwater Monitoring for Fiscal Year 2007, Rev. 0, U.S. Department of Energy, Richland Operations Office, Richland, Washington.

EPA, Ecology, and DOE, 1996, Declaration of the Record of Decision for the 300-FF-1 and 300-FF-5 Operable Units, Washington State Department of Ecology, U.S. Environmental Protection Agency, and U.S. Department of Energy, Olympia, Washington.

EPA/ROD/R10-96/134, 1996, Record of Decision for the USDOE Hanford 100-HR-3 and 100-KR-4 Operable Units Interim Remedial Actions, U.S. Environmental Protection Agency, Washington State Department of Ecology, and U.S. Department of Energy, Olympia, Washington.

Permit No. WA7890008967, 2007, Dangerous Waste Portion of the Resource Conservation and Recovery Act Permit for the Treatment, Storage, and Disposal of Dangerous Waste, Rev. 8B, dated January 2007, as amended, Washington State Department of Ecology, Olympia, Washington.

PNNL-11573, 1997, Groundwater Monitoring Plan for the 183-H Solar Evaporation Basins, Rev. 0, Pacific Northwest National Laboratory, Richland, Washington.

Resource Conservation and Recovery Act of 1976, Public Law 94-580, as amended, 90 Stat. 2795, 42 U.S.C. 6901 , et seq.

SGW-37292, 2008, Results of Groundwater Monitoring for the 300 Area Process Trenches, Reporting Period July-December 2007, Fluor Hanford, Inc., Richland, Washington.

SGW-37294, 2008, Results of Groundwater Monitoring for the 183-H Solar Evaporation Basins, Reporting Period July-December 2007, Fluor Hanford, Inc., Richland, Washington.

WAC 173-303-645, "Release from Regulated Units," Washington Administrative Code.

WHC-SD-EN-AP-185, 1995. Groundwater Monitoring Plan for the 300 Area Process Trenches, Rev. 0A, Westinghouse Hanford Company, Richland, Washington. 
SGW-39299, Rev. 0

This page intentionally left blank. 